\title{
Manusia dan Teknologi: Perilaku Interaksi Interpersonal Sebelum dan Sesudah Media Digital
}

\section{Human and Technology: Interpersonal Interaction Behavior Before and After Digital Media}

\author{
Ferdinand Eskol Tiar Sirait \\ Program Pascasarjana Ilmu Komunikasi, Fakultas Ilmu Sosial Dan Ilmu Politik, \\ Universitas Indonesia, Indonesia
}

Diterima: 30 September 2020; Direview: 10 Oktober 2020; Disetujui:17 Oktober 2020

Coresponding Email: ferdinand@upnvi.ac.id

\begin{abstract}
Abstrak
Artikel ini bertujuan untuk melihat bagaimana perilaku interaksi interpersonal sebelum dan sesudah media digtal. Metode penulisan artikel ilmiah ini menggunakan metode kualitatif deskritif melalui studi kepustakaan, yaitu riset berdasarkan studi pustaka dan analisis perkembangan permasalahan di masyarakat. Kajian ini menyimpulkan bahwa Dengan komunikasi interpersonal seseorang lebih merasa dihargai, sehingga akan tumbuh ide-ide kreatif guna pengembangan diri. Kehadiran media sosial bukan hanya berdampak pada komunikasi interpersonal tetapi juga berdampak pada hubungan interpersonal. Media sosial telah mengubah sikap dan gaya hidup seseorang, orang yang pada mulanya bersikap ramah akan mengalami perubahan menjadi cuek dengan keadaan disekitarnya karena perhatiannya telah dialihkan pada media sosial. Perubahan-perubahan dalam hubungan sosial (social relationships) atau sebagai perubahan terhadap keseimbangan (equilibrium) hubungan sosial dan segala bentuk perubahanperubahan pada lembaga-lembaga kemasyarakatan didalam suatu masyarakat, yang mempengaruhi sistem sosialnya, termasuk didalamnya nilai-nilai, sikap dan pola perilaku diantara kelompok-kelompok dalam masyarakat. Perubahan sosial positif seperti kemudahan memperoleh dan menyampaikan informasi, memperoleh keuntungan secara sosial dan ekonomi. Sedangkan perubahan sosial yang cenderung negatif seperti munculnya kelompok - kelompok sosial yang mengatasnamakan agama, suku dan pola perilaku tertentu yang terkadang menyimpang dari norma - norma yang ada.
\end{abstract}

Kata Kunci: Interaksi, Media Digital, Komunikasi Interpersonal.

\begin{abstract}
This article aims to examine the behavior of interpersonal interactions before and after digital media. The method of scientific articles uses descriptive qualitative methods through literature study, namely research based on literature studies and analysis of the development of problems in society. This study concludes that with interpersonal communication a person is more interested, so that creative ideas will grow for selfdevelopment. The presence of social media not only has an impact on interpersonal communication but also has an impact on interpersonal relationships. Social media has changed the attitude and style of a person, people who are initially friendly will experience changes to be ignorant of their surroundings because their attention has been diverted to social media. Changes in social relationships or changes as a balance (equilibrium) of social relations and all forms of changes in social institutions within a society, which affect the social system, including values, attitudes and behavior patterns among groups in society. Positive social changes such as obtaining information, obtaining social and economic benefits. Meanwhile, social changes that tend to be negative include social groups acting on behalf of religion, ethnicity and certain behavior patterns that sometimes deviate from existing norms.
\end{abstract}

Keywords: Interaction, Digital Media, Interpersonal Communication.

How to Cite: Ferdinand, E.T.S. ((2020). Manusia Dan Teknologi: Perilaku Interaksi Interpersonal Sebelum Dan Sesudah Media Digital. Journal of Education, Humaniora and Social Sciences (JEHSS). 3(2): 524-532. 


\section{PENDAHULUAN}

Kehadiran teknologi memberikan pengaruh sangat besar dalam kehidupan manusia. Dengan adanya teknologi, kehidupan dan kegiatan manusia menjadi sangat mudah dan cepat. Disadari atau tidak, kita menjadi tergantung kepada teknologi. Teknologi membentuk perasaan, pikiran, dan tindakan manusia. Manusia memiliki hubungan simbolik dengan teknologi. Kita menciptakan teknologi dan teknologi pada gilirannya menciptakan kembali siapa diri kita. McQuail (2010) menyatakan bahwa internet telah membawa banyak perubahan bagi masyarakat. Sebagai new media, internet tidak hanya memiliki fungsi sebagai alat produksi dan distribusi pesan sebagaimana media tradisional lainnya, namun juga sebagai media penyimpanan pesan. Internet telah membawa manusia memasuki era baru, era semua hal dapat berbentuk digital dan penetrasi masyarakat akan dunia virtual semakin gencar. Penggunaan ponsel pintar dan akses terhadap media sosial semakin meningkat setiap hari nya. Seluruh orang di seluruh dunia dapat terhubung satu sama lain hanya dengan satu aplikasi jejaring pertemanan.

Dengan adanya kemudahan akses dan perkembangan teknologi ini, tidak heran para pengguna internet dan aplikasi media sosial memiliki motif untuk dapat terhubung satu sama lain, salah satu motifnya adalah untuk membangun hubungan dengan orang lain. Penggunaan media daring (digital) atau media berbasis Internet mengalami peningkatan yang cukup pesat. Dampak yang dapat ditimbulkan dari media digital meliputi: cyberbullying, hoax (berita bohong), pornografi, kekerasan seksual, kecanduan terhadap kekerasan dan perceraian. Salah satu dampak lainnya yang juga harus diantisipasi adalah pernikahan di usia muda atau remaja. Hasil temuan Jaringan Penggiat Literasi Digital (Japelidi) menunjukkan bahwa remaja yang merupakan kelompok digital native dimana mereka tidak perlu diajari untuk dapat menggunakan Internet ketika mengakses informasi yang mereka butuh (Kurnia \& Astuti, 2017). Bahkan media sosial mampu meniadakan status sosial yang sering kali sebagai penghambat komunikasi. Kehadiran Twitter, Facebook, Google+ dan sejenisnya mampu membuat orang-orang tanpa harus bertemu bisa saling berinteraksi (Watie, 2016).

Komunikasi merupakan aktivitas dasar manusia, dengan berkomunikasi manusia dapat berhubungan satu sama lain dalam kehidupan sehari-hari dimanapun manusia itu berada. (Wijaya, 2013). Komunikasi interpersonal melibatkan suatu bentuk aktivitas timbal balik (mutual activity), interaksi (interaction), atau pertukaran (exchange). Komunikasi interpersonal adalah pertukaran pesan di antara orang, dengan sebuah "pesan" menjadi perilaku orang lain, yang dimaksudkan atau tidak, dapat diinterpretasikan oleh seorang penerima tanpa batasan tentang jumlah orang yang terlibat pertukaran tersebut. Komunikasi interpersonal merupakan suatu perantara atau alat pendukung dalam bentuk bahasa lisan, bahasa tulisan, bahasa tubuh, dan lain-lain sehingga isi komunikasi dapat dipahami oleh penerima pesan (Pratiwi \& Sukma, 2013).

Uraian tentang individu yang saling berkomunikasi dalam lingkungannya akhirnya menjadi media fardhu bagi manusia untuk menyampaikan idenya (Supratman, 2016). Semakin baik komunikasi yang dibangun antara orang tua dan remaja maka akan semakin menghindarkan remaja dari perilaku bullying. Anak remaja yang melakukan perilaku bullying di sekolah biasanya berasal dari keluarga yang broken home (Usman, 2013). Maka disinilah fungsi dari komunikasi interpersonal berada yaitu sebagai sharing ideas and knowledge antar manusia. Komunikasi Interpersonal adalah komunikasi antarperorangan dan bersifat pribadi yang terjadi secara langsung (tanpa medium) ataupun tidak langsung (melalui medium) (Bungin, 2006). Komunikasi ini terjadi antara dua orang atau lebih dan sifatnya informal serta membutuhkan hubungan emosional di antara pelaku komunikasi. Komunikasi ini biasanya terjadi antara teman dekat, suami istri, sahabat serta orang tua dan anak, dengan kata lain individu yang memiliki hubungan emosional tinggi.

Komunikasi interpersonal tersusun dari banyak proses yang saling terkait, terdiri dari produksi pesan, pengolahan pesan, koordinasi interaksi, dan persepsi sosial (Berger \& Calabrese, 2014). Produksi pesan adalah proses menghasilkan perilaku verbal dan perilaku nonverbal yang dimaksudkan untuk menyampaikan suatu keadaan batin kepada orang. Pengolahan pesan meliputi menginterpretasi perilaku dan implikasiimplikasi perilaku mereka. Koordinasi interaksi 
adalah proses menyelaraskan aktivitas produksi pesan dan pengolahan pesan sehingga menghasilkan pertukaran yang lancar dan koheren. Terakhir, persepsi sosial adalah kumpulan proses-proses yang dijalani untuk memaknai dunia sosial, termasuk menyelami diri sendiri, orang lain, hubungan sosial, dan pranata sosial.

Tujuan komunikasi interpersonal yaitu: (1) Mendapat rangsangan, stimulasi ini dibutuhkan oleh setiap manusia, jika tidak manusia akan mengalami kemunduran dan mati sehingga rangsangan yang dimaksud disini yaitu kontak pribadi antara manusia; (2) Mendapatkan pengetahuan diri, Adanya kontak dengan orang lain membuat kita akan mengetahui diri sendiri dan menambah pengetahuan tentang diri kita sendiri melalui apa yang kita yakini dan orang lain pikirkan tentang kita; (3) Memaksimalkan kesenangan, dan meminimalkan penderitaan (Devito, 2013). Komunikasi yang dibangun antara kita dengan orang lain antara lain agar memaksimalkan kesenangan dan meminimalkan penderitaan karena berbagai rasa seperti emosi, nasib, penderitaan dan kesenangan menjadi keperluan dalam menjalani kehidupan.

Adler dan Rodman menjelaskan tipe-tipe komunikasi yaitu komunikasi verbal termasuk komunikasi vokal adalah bahasa lisan, lalu yang termasuk dalam komunikasi non vokal yaitu bahasa tertulis Adler \& Rodman, (1985) dalam Darmawan, et al (2019). Kemudian komunikasi nonverbal yang tergolong dalam komunikasi vokal adalah nada, suara, desah, jeritan dan kualitas vokal. Sedangkan yang termasuk klasifikasi komunikasi non vokal yaitu isyarat, gerakan tubuh, penampilan, ekspresi wajah dll. Efektivitas antar pribadi dapat dilihat dari tiga sudut pandang, yaitu antara lain: a) Sudut pandang humanistik: pada sudut pandang ini menekankan pada keterbukaan, empati, dukungan, sikap positif dan kesetaraan. b) Sudut pandang pragmatis: dipusatkan pada perilaku spesifik yang harus digunakan oleh komunikator untuk mendapatkan hasil yang dikehendaki. Pada sudut pandang ini ditekankan pada lima kualitas yaitu: rasa percaya diri, kebersatuan, manajemen interaksi, daya ekspresi, orientasi pada pihak lain. c) Sudut pandang pergaulan sosial dan kesetaraan. Dipusatkan pada pertukaran manfaat dan biaya, serta implikasi dari pola pertukaran ini terhadap hubungan. Empat kualitas dari model pragmatis ini yaitu: bertukar manfaat, menanggung biaya bagian, mengintensifkan manfaat pada saat biaya meningkat dan memperbesar manfaat untuk mengurangi daya tarik alternatif (Kurniawati, 2014).

Hal ini sangat diperlukan dalam pengembangan hubungan antar pribadi sehingga dapat lebih meningkatkan hubungan dengan adanya faktor-faktor tersebut. Penelitian terdahulu yang sudah dilakukan menunjukan bahwa keefektifan komunikasi antar personal adalah berada di komunikator yang memiliki posisi penting sebagai salah satu komponen komunikasi yang membangun efektivitas komunikasi personal dengan anggota masyarakat (Bakti, Dewi, Romli, \& Budiana, 2015).

Devito menguraikan lima tahap dalam pengembangan hubungan. Kelima tahap ini adalah kontak, keterlibatan, keakraban, perusakan, dan pemutusan (Devito, 2013): (a) Kontak, pada tahap pertama terjadi pembuatan kontak. Pada tahap ini terjadi pemutusan apakah hubungan ini berlanjut atau tidak. Pada tahap ini penampilan fisik begitu penting, karena dimensi fisik paling terbuka untuk diamati secara mudah. Meskipun demikian, kualitas-kualitas lain seperti sikap bersahabat, kehangatan, keterbukaan, dan dinamisme juga terungkap pada tahap ini, (b) Keterlibatan, pada tahap keterlibatan adalah tahap pengenalan lebih jauh, ketika mengikatkan diri sendiri untuk lebih mengenal orang lain dan juga mengungkapkan diri, (c) Keakraban, pada tahap keakraban terjadi pengikatan diri lebih jauh pada orang tersebut, komitmen pada tahap ini mempunyai berbagai bentuk seperti: perkawinan, membantu orang tersebut, atau mengungkapkan rahasia terbesar anda, (d) Perusakan, pada tahap ini merupakan penurunan hubungan, ketika ikatan di antara kedua pihak melemah. Dan akan terasa bahwa hubungan tidaklah sepenting sebelumnya, dan (e) Pemutusan, pada tahap pemutusan adalah pemutusan ikatan yang mempertalikan kedua belah pihak. Jika bentuk ikatan adalah perkawinan, pemutusan hubungan dilambangkan dengan perceraian.

Dalam tahap persahabatan dan pertemanan biasanya muncul dari adanya kesamaan dan kepentingan yang terjalin selama menjalani suatu hubungan (Kurniawati, 2014). Interaksi yang dilakukan dan menyukai apa yang ditemukan di satu sama lain, mereka mulai menganggap diri mereka sebagai teman atau sebagai menjadi teman. Hal ini menjadi tahap awal yang baru lahir, 
seperti embrio, persahabatan. Pada tahap ini terdapat kriteria lain yaitu kepercayaan, yang mengukuhkan persahabatan. Setelah memperoleh kepercayaan banyak hambatan komunikasi yang akan ditemui seperti kurangnya komunikasi akan tetapi jika dapat melewatinya komunikasi dapat lebih terbuka. Ketika pertemanan mengalami perubahan atau memburuk diakibatkan karena kualitas dan kuantitas komunikasi. Teman-teman menjauh dan mengalami sakit hati satu sama lain, mereka cenderung kurang sering berinteraksi dan berbicara tentang topik yang kurang pribadi dan konsekuensional.

Dalam praktiknya, pengguna media digital dapat menyajikan citra diri melalui foto yang ditampilkan pada pengguna lainnya. Satu hal tersebut merupakan ujung tombak atau bisa dikatakan sebagai citra diri utama untuk melakukan proses pertukaran informasi diri sebagai rangkaian pengembangan hubungan yang disebut self disclosure. Pembukaan diri atau self disclosure dalam komunikasi online terjadi ketika informasi diri diberitahukan kepada seseorang melalui internet.

Penelitian sebelumnya yang dilakukan oleh Mayuni et al (2017) menunjukkan bahwa semakin tinggi penggunaan media sosial maka semakin tinggi pula tatap muka interaksi sosial. Sejalan dengan itu Sisrazeni, S. (2018) dalam penelitiannya menujukkan hasil bahwa antara media sosial dengan interaksi sosial Mahasiswa memiliki hubungan yang signifikan 5\% dengan nilai $r$ hitung 0,74. Hal ini berarti semakin tinggi media sosial maka semakin tinggi pula interaksi sosialnya. Marlina, (2018). Dalam peneitiannya menunjukkan hasil bahwa menunjukan adanya jarak yang tercipta antara orang tua dan anak, ketika orang tua lebih sering memegang alat komunikasi berupa Handphone kemudian terhubung dengan orang lain diluar sana, ketika hal tersebut terjadi maka anak merasa tidak dihargai sampai tingkat pengakuan dari anak tersebut, bahwa mereka ingin sosok orang tua baru, yang dapat mereka ajak bermain sambil bercanda dan memberikan perhatian yang seharusnya. Menarik untuk dikaji lebih lanjut, fokus masalah makalah ini adalah tentang bagaimana komunikasi interpersonal sebelum dan sesudah media digital muncul dalam upaya untuk pengurangan ketidakpastian demi tercapainya porsi hubungan yang diinginkan

\section{METODE PENELITIAN}

Metode penulisan artikel ilmiah ini menggunakan metode kualitatif deskritif melalui studi kepustakaan, yaitu riset berdasarkan studi pustaka dan analisis perkembangan permasalahan di masyarakat. Permasalahan yang terjadi di masyarakat saat ini khususnya permasalahan di dunia Internet, penggunaan media di dunia Internet yang tidak bijak dan benar dikarenakan literasi media yang kurang hingga perilaku dan tujuan penggunaan media yang tidak benar membuat mediamedia baru seperti media sosial di Internet yang tercipta karena perkembangan teknologi menjadi alat komunikasi untuk hal-hal buruk. Analisis riset yang dilakukan pada permasalahan ini adalah studi pustaka dengan membaca dan menganalisa teori-teori mengenai interaksi sosial dan media digital agar dapat mengambil suatu kesimpulan untuk hasil penelitian.

\section{HASIL DAN PEMBAHASAN}

Dalam perkembangannya, internet yang pada tujuan awalnya ditujukan untuk penggunaan yang lebih formal seperti jaringan koneksi antar instansi Pendidikan Tinggi, hingga untuk urusan keamanan negara dan, kini justru berkembang menjadi alat yang memudahkan manusia untuk melakukan begitu banyak hal. Perkembangan fungsi ini sejalan dengan pemikiran Sartré (1943) dalam (Hatzimoysis, 2011) yang terkenal, yaitu eksistensi melampaui esensi.

Mungkin, dalam beberapa dekade silam, tidak ada yang memprediksi bahwa sebuah jaringan interkoneksi, yang melibatkan teknologi super canggih dan mahal seperti kabel bawah laut, pancaran geo-satelit, dan infrastruktur pengiriman data super cepat, pada akhirnya hanya digunakan untuk hal sepele seperti mencari jodoh. Fenomena mencari jodoh melalui Tinder, selain dibahas melalui uncertainty reduction theory, juga dapat diperkuat oleh social exchange theory yang digagas oleh Thibaut \& Kelley dalam Griffin (2012), dimana teori tersebut menjelaskan bahwa dalam sebuah hubungan, tiap-tiap pihak yang terlibat saling memperhitungkan cost yang 
dikeluarkan dan reward yang didapat dari hubungan yang dijalin, serta seberapa hubungan alternatif (CLalt) bisa dirasa lebih menguntungkan dibandingkan hubungan utama yang sedang dijalin.

Sederhananya, apabila reward yang didapat lebih besar dari cost yang dikeluarkan, maka hubungan akan berlanjut dan berkembang. Apabila reward yang didapat seimbang dengan cost yang dikeluarkan, maka hubungan akan berlanjut tetapi belum tentu berkembang. Sedangkan apabila reward yang didapatkan lebih kecil dari cost yang dikeluarkan, maka hubungan akan berakhir, namun kini kenyataannya hal itu lah yang terjadi, dimana McLuhan dalam Morissan, dkk (2010) menyatakan bahwa memang betul manusia yang menciptakan teknologi, tetapi pada akhirnya teknologi lah yang menentukan perasaan, pikiran, dan perilaku kita.

Era digital telah membawa berbagai perubahan yang baik sebagai dampak positif yang bisa gunakan sebaik-baiknya. Namun dalam waktu yang bersamaan, era digital juga membawa banyak dampak negatif, sehingga menjadi tantangan baru dalam kehidupan manusia di era digital ini. Tantangan pada era digital telah pula masuk ke dalam berbagai bidang seperti politik, ekonomi, sosial budaya, pertahanan, keamanan, dan teknologi informasi itu sendiri. Era digital terlahir dengan kemunculan digital, jaringan internet khususnya teknologi informasi komputer. Media baru era digital memiliki karakteristik dapat dimanipulasi, bersifat jaringan atau internet.

Media massa beralih ke media baru atau internet karena ada pergeseran budaya dalam sebuah penyampaian informasi. Kemampuan media era digital ini lebih memudahkan masyarakat dalam menerima informasi lebih cepat. Dengan media internet membuat media massa berbondong-bondong pindah haluan. Semakin canggihnya teknologi digital masa kini membuat perubahan besar terhadap dunia, lahirnya berbagai macam teknologi digital yang semakin maju telah banyak bermunculan. Berbagai kalangan telah dimudahkan dalam mengakses suatu informasi melalui banyak cara, serta dapat menikmati fasilitas dari teknologi digital dengan bebas dan terkendali.

Era digital juga membuat ranah privasi orang seolah-olah hilang. Data pribadi yang terekam di dalam otak komputer membuat penghuni internet mudah dilacak, baik dari segi kebiasaan berselancar atau hobi. Era digital bukan persoalan siap atau tidak dan bukan pula suatu opsi namun sudah merupakan suatu konsekuensi. Teknologi akan terus bergerak ibarat arus laut yang terus berjalan ditengah-tengah kehidupan manusia. Maka tidak ada pilihan lain selain menguasai dan mengendalikan teknologi dengan baik dan benar agar memberi manfaat yang sebesarbesarnya.

Teknologi digital masa kini yang semakin canggih menyebabkan terjadinya perubahan besar dunia. Manusia telah dimudahkan dalam melalukan akses terhadap informasi melalui banyak cara, serta dapat menikmati fasilitas dari teknologi digital dengan bebas, namun dampak negatif muncul pula sebagai mengancam. Tindak kejahatan mudah terfasilitasi, game online dapat merusak mental generasi muda, pornografi, dan pelanggaran hak cipta mudah dilakukan, dan lain-lain.

Telah terjadi revolusi digital sejak tahun 1980an dengan perubahan teknologi mekanik dan analog ke teknologi digital dan terus berkembang hingga hari ini. Perkembangan teknologi ini menjadi masif setelah penemuan personal komputer yaitu sistem yang dirancang dan diorganisasir secara otomatis untuk menerima dan menyimpan data input, memprosesnya, dan menghasilkan output dibawah kendali instruksi elektronik yang tersimpan di memori yang dapat memanipulasi data dengan cepat dan tepat.

Perkembangan teknologi komputer digital khususnya mikroprosesor dengan kinerjanya terus meningkat, dan teknologi ini memungkinkan ditanam pada berbagai perangkat yang dimiliki secara personal. Perkembangan teknologi transmisi termasuk jaringan komputer juga telah memicu para pengguna internet dan penyiaran digital. Ditambah perkembangan ponsel, yang tumbuh pesat menjadi penetrasi sosial memainkan peran besar dalam revolusi digital dengan memberikan hiburan di mana-mana, komunikasi, dan konektivitas online.

Lahirnya situs jejaring sosial yang merupakan sebuah pelayanan berbasis web, memungkinkan penggunanya untuk membuat profil, melihat list pengguna yang tersedia, serta mengundang atau menerima teman untuk bergabung dalam situs tersebut. Hubungan antara perangkat mobile dan halaman web internet melalui "jaringan sosial" telah menjadi standar dalam 
komunikasi digital. Situs pertemanan bernama Friendster terus berkembang ke situs-situs seperti MySpace, Facebook, Twitter dan lain-lain. Revolusi digital merupakan kemampuan untuk dengan mudah memindahkan informasi digital antara media, dan untuk mengakses atau mendistribusikannya jarak jauh.

Kita melihat saat ini banyak orang yang tidak menyadari pentingnya komunikasi interpersonal secara langsung. Padahal dengan berkomunikasi secara langsung (face to face) terdapat banyak keuntungan bila dibandingkan dengan komunikasi di dunia maya. Namun pada kenyataannya kebanyakan orang lebih memilih untuk berkomunikasi di dunia maya, semua dilakaukan dalam dunia maya, padahal harus kita sadari bahwa apa yang terlihat di dunia maya itu belum tentu sesuai dengan kenyataan yang sebenarnya. Berkomunikasi di dunia maya kita jarang untuk mendapatkan feedback atau tanggapan dari lawan bicara. Berbanding terbalik jika kita melakukan komunikasi interpersonal.

Adanya media digital akan memberikan dampak positif dan negatif dalam kehidupan manusia, diantaranya Dengan media sosial, kita dapat dengan mudah berinteraksi dengan siapa saja termasuk artis favorit kita yang juga menggunakan media digital, terkenal seperti Facebook dan Twitter. Media digital membuat kita bisa memiliki banyak koneksi dan jaringan yang luas. Tentu saja hal ini berdampak positif bagi orang yang ingin mendapatkan teman atau pasangan hidup dari tempat yang jauh atau negara asing. Di era media digital seperti sekarang ini, hubungan jarak jauh bukan lagi halangan besar karena kita tetap dapat berinteraksi dengan orang lain kapan saja walaupun dipisahkan oleh jarak yang cukup jauh. Lebih mudah dalam mengekspresikan diri Media digital memberikan sarana baru bagi manusia dalam mengekspresikan diri. Orang biasa, orang pemalu, atau orang yang selalu gugup mengungkapkan pendapat di depan umum akhirnya mampu menyuarakan diri mereka secara bebas. Dengan media digital, siapapun dapat menyebarkan informasi baru kapan saja, sehingga orang lain juga dapat memperoleh informasi yang tersebar di media digital kapan saja.

Kemunculan media digital menjadikan manusia cenderung memberikan jarak antar manusia. Sebelum kemunculan media digital manusia intens melakukan komunikasi, tetapi munculnya media digital memberikan dampak negatif dalam kehidupan. Orang yang terjebak dalam media digital memiliki kelemahan besar yaitu berisiko mengabaikan orang-orang di kehidupannya sehari-sehari. Karena mudahnya berinteraksi melalui media digital, maka seseorang akan semakin malas untuk bertemu secara langsung dengan orang lain. Dengan kepraktisan dan kemudahan menggunakan media digital, maka orang-orang akan semakin tergantung pada media digital, dan pada akhirnya akan menjadi kecanduan terhadap internet. Seperti di kehidupan sehari-hari, jika kita tidak menyeleksi orang- orang yang berada dalam lingkaran digital kita, maka kita akan lebih rentan terhadap pengaruh buruk. Masalah privasi Dengan media digital, apapun yang kita unggah bisa dengan mudah dilihat oleh orang lain. Hal ini tentu saja dapat membocorkan masalah-masalah pribadi kita. Oleh karena itu, sebaiknya tidak mengunggah hal-hal yang bersifat privasi ke dalam media digital. Dengan media digital siapapun bebas mengeluarkan pendapat, opini, ide gagasan dan yang lainnya, akan tetapi kebeasan yang berlebihan tanpa ada kontrol sering menimbulkan potensi konflik yang akhirnya berujung pada sebuah perpecahan.

Seharusnya melihat kondisi saat ini, di mana media digital telah banyak mengambil peran dalam kehidupan manusia, manusia harus lebih meningkatkan komunikasi interpersonalnya. Karena pustakawan yang kerjanya langsung berhubungan dengan masyarakat, dimana masyarakat saat ini juga lebih banyak memilih untuk menggunakan meda sosial guna mencari informasi yang dibutuhkannya. Manusia harus mempunyai skill dalam berkomunikasi untuk melayani pemustaka dengan melakukan komunikasi interpersonal. Komunikasi interpersonal yang baik yang dilakukan oleh setiap manusia akan mampu mengalihkan orang lain dalam menggunakan media sosial. Seseorang yang menggunakan media sosial harus bisa mengontrol diri tanpa harus mengabaikan tugas dan fungsinya. Ia juga harus cermat dalam penggunaan media sosial, yaitu mengambil informasi-informasi yang benar-benar berguna. Media sosial diharapkan untuk mampu mengendalikan diri agar tidak terlena dalam menggunaakan media sosial yang bisa 
mengurangi kapasitas komunikasi interpersonalnya, karena komunikasi ini sangat penting dilakukan di setiap manusia.

Dari hasil penelitian yang dilakukan, media sosial memiliki dampak positif dan negatif. Dampak positif penggunaan media sosial secara nyata telah membawa pengaruh terhadap perubahan sosial masyarakat kearah yang lebih baik tetapi dampak negatif cenderung membawa perubahan sosial masyarakat yang menghilangkan nilai - nilai atau norma di masyarakat Indonesia. Dengan hadirnya media sosial sebagai teknologi baru, tentu saja cara hidup manusia juga akan mengalami perubahan. Beberapa perubahan adalah semakin efektif dan efisiennya manusia dalam memperoleh informasi tidak terhalang waktu, tempat dan biaya yang tidak terlalu mahal.

Perubahan-perubahan dalam hubungan sosial (social relationships) atau sebagai perubahan terhadap keseimbangan (equilibrium) hubungan sosial dan segala bentuk perubahan- perubahan pada lembaga-lembaga kemasyarakatan didalam suatu masyarakat, yang mempengaruhi sistem sosialnya, termasuk didalamnya nilai-nilai, sikap dan pola perilaku diantara kelompok-kelompok dalam masyarakat. Masyarakat dapat berkomunikasi langsung dengan presiden melalui media sosial guna menyampaikan saran kritik dan ide yang membangun. Jika dalam metode konvensional masyarakat harus menjadi wakil rakyat/anggota DPR terlebih dahulu dan atau melakukan demonstrasi didepan istana kepresidanan guna menyampaikan aspirasi, sekarang cara tersebut cenderung ditinggalkan.

Dari sisi ekonomi semakin tingginya minat masyarakat terhadap media sosial, tidak sedikit masyarakat kita memperoleh keuntungan dengan berbisnis melalui media sosial. Maka masyarakat akan semakin tergantung dengan media sosial, dan hal ini akan mempengaruhi kehidupan mereka sehari-hari. Mengakses media sosial setiap saat telah menjadi kebutuhan manusia yang baru untuk selalu meng- update informasi karena media sosial telah menjadi sumber informasi yang lebih aktual dibandingkan media lainnya.

Pengaruh negatif terhadap perubahan sosial masyarakat diantaranya: sering terjadi konflik antar kelompok-kelompok tertentu dengan berlatar belakang suku, ras maupun agama. Mengatasnamakan agama, kelompok tertentu memiliki pengikut dengan jumlah yang banyak pada media sosial cenderung memanfaatkan momen tertentu untuk menggerakkan massa dalam kegiatan tertentu. Secara langsung media sosial berpengaruh terhadap terbentukknya kelompokkelompok sosial tersebut dengan menanamkan prinsip, nilai dan akidah tertentu untuk menjadi perubah sistem. Bahkan dengan media sosial kelompok-kelompok tersebut dengan mudah mempengaruhi kondisi stabilitas sebuah negara.

Ada pula berlatar belakang kesenjangan sosial yang sering mengundang komentar dan berujung konflik. Pola perilaku masyarakat yang menyimpang juga sering di blow up pada media sosial seperti grop / komunitas penyuka sesama jenis seperti kaum gay dan lesbian.

Jika dilihat dari sisi interaksi sosial pengaruh perubahan sosial di masyarakat terjadi karena semakin mudahnya manusia berinteraksi melalui media sosial, maka interaksi sosial di dunia nyata akan turut berkurang. Manusia tidak perlu lagi saling bertemu secara langsung untuk berkomunikasi, sehingga hal ini akan membentuk pola hidup masyarakat yang semakin tertutup.

Fungsi dari internet yang awalnya digunakan untuk supporting teknologi informasi dan komunikasi guna memudahkan manusia mengirimkan data digital di sektor pendidikan, bisnis, dan pertahanan keamanan, akhirnya berkembang fungsinya melebihi esensi subtstansialnya. Internet mendorong perkembangan industri untuk berinovasi ke dalam bentuk yang mampu menjangkau seluruh kebutuhan manusia yang tidak lagi sebatas primer, sekunder, dan tertier, melainkan kepada kebutuhan manusia berinteraksi secara virtual. Media sosial menjadi primadona baru dalam jagat komunikasi manusia modern. Pertumbuhan terhadap aplikasi media sosial dengan peruntukan dan fungsi yang beragam menjadi sebuah realita baru dan tinder adalah salahsatunya.

Kehadiran media sosial yang merupakan suatu perkembangan dari teknologi telah mengubah paradigma dan pola komunikasi masyarakat. Adanya media ini membuat komunikasi tidak hanya dilakukan satu arah tetapi bisa dilakukan dua arah. Penggunaan media sosial yang tidak efektif akan menimbulkan dampak yang luar biasa salah satunya pengguna akan 
menghabiskan banyak waktu hanya sekedar untuk mengakses berbagai macam media sosial. Tetapi penggunaan media sosial yang efektif akan mempermudah seseorang untuk mendapatkan informasi yang memang benarbenar dibutuhkan sehingga mampu menimbulkan ide-ide kreatif guna menunjang pengembangan diri seseorang.

\section{SIMPULAN}

Dampak dari media sosial bagisetiap orang yang sangat terlihat adalah turunnya aktivitas komunikasi interpersonal. Seseorang terkadang lebih cenderung untuk menggunakan atau mengakses media sosial daripada melakukan komunikasi interpersonal. Fenomena ini dapat mengakibatkan kurangnya kepedulian antar sesama sehingga akan juga berdampak pada hubungan interpersonal. Padahal kita ketahui bahwa komunikasi interpersonal antar sesama ini sangat penting mengingat saat ini kemajuan teknologi telah mengubah eksistensi seseorang. Salah satu caranya adalah selalu melakukan komunikasi interpersonal dalam menyelesaikan setiap permasalahan yang ada dan menjaga hubungan interpersonal dengan baik.

Dampak positif dari media sosial adalah memudahkan kita untuk berinteraksi dengan banyak orang, memperluas pergaulan, jarak dan waktu bukan lagi masalah, lebih mudah dalam mengekspresikan diri, penyebaran informasi dapat berlangsung secara cepat, biaya lebih murah. Sedangkan dampak negatif dari media sosial adalah menjauhkan orang-orang yang sudah dekat dan sebaliknya, interaksi secara tatap muka cenderung menurun, membuat orang-orang menjadi kecanduan terhadap internet, menimbulkan konflik, masalah privasi, rentan terhadap pengaruh buruk orang lain.

Adanya media sosial telah mempengaruhi kehidupan sosial dalam masyarakat. Perubahanperubahan dalam hubungan sosial (social relationships) atau sebagai perubahan terhadap keseimbangan (equilibrium) hubungan sosial dan segala bentuk perubahan- perubahan pada lembagalembaga kemasyarakatan didalam suatu masyarakat, yang mempengaruhi sistem sosialnya, termasuk didalamnya nilai-nilai, sikap dan pola perilaku diantara kelompok-kelompok dalam masyarakat. Perubahan sosial positif seperti kemudahan memperoleh dan menyampaiakan informasi, memperoleh keuntungan secara sosial dan ekonomi. Sedangkan perubahan sosial yang cenderung negatif seperti munculnya kelompok-kelompok sosial yang mengatasnamakan agama, suku dan pola perilaku tertentu yang terkadang menyimpang dari norma - norma yang ada

\section{DAFTAR PUSTAKA}

Bakti, I., Dewi, E. A. S., Romli, R., \& Budiana, H. R. (2015). Analisis faktor personal pada sumber komunikasi dalam pengelolaan tanaman obat keluarga di Jawa Barat. Jurnal Kajian Komunikasi, 3(2), 133-139.

Berger, C. R. \& Calabrese, R. J. (2014). Some explorations in initial interaction and beyond: toward a developmental theory of interpersonal communication. Human Communication Research, 1(2), 99112. https://doi.org/10.1111/j.1468-2958.1975. tb00258.x

Bungin, B. (2006). Sosiologi komunikasi edisi pertama. Jakarta: Prenada Media Group

Darmawan, C., Silvana, H., Zaenudin, H. N., \& Effendi, R. (2019). Pengembangan hubungan interpersonal remaja dalam penggunaan media sosial di Kota Bandung. Jurnal Kajian Komunikasi, 7(2), 159-169.

Devito, J. A. (2013). The interpersonal communication. New York: Peson Education

Hatzimoysis, A. (Ed.). (2011). Self-knowledge. Oxford: Oxford University Press.

Kurnia, N. \& Astuti, S. I. (2017). Peta gerakan literasi digital di Indonesia: studi tentang pelaku, ragam kegiatan, kelompok sasaran dan mitra. Informasi, 47(2), 149-166.

Kurniawati, N. (2014). Komunikasi antarpribadi. Yogyakarta: Graha Ilmu.

Marlina, M. (2018). PENGARUH MEDIA SOSIAL TERHADAP INTENSITAS HUBUNGAN KOMUNIKASI ORANG TUA DAN ANAK USIA DINI. Komunikasiana: Journal of Communication Studies, 1(1).

Mayuni, I Gst. A. A. R , Gelgel, N. M. R. A, Pascarani, N. N. D. (2017). Pengaruh Penggunaan Media Sosial Terhadap Interaksi Sosial Pada Sekaa Teruna Desa Adat Kuta,Badung, Bali, online (file:///C:/Users/ASUS\%20X200MA/Downloads/35553-1309-69976-1-10-20171116.pdf, diakses pada 10 Oktober 2020)

Pratiwi, S. W. \& Sukma, D. (2013). Komunikasi interpersonal antar siswa di sekolah dan implikasinya terhadap pelayanan bimbingan dan konseling. Konselor, 2(1), 324-329. https://doi.org/10.24036/02013211268-0- 00. 
Sisrazeni, S. (2018). Hubungan Penggunaan Media Sosial dengan Interaksi Sosial Mahasiswa Jurusan Bimbingan Konseling Tahun 2016/2017 iain batusangkar. Proceeding IAIN Batusangkar, 1(2), 437448.

Supratman, L. P. \& Rafiqi, A. (2016). Kajian etnografi komunikasi pada gaya berkomunikasi komunitas hansamo modern dance boys di Kota Bandung. Jurnal Kajian Komunikasi, 4(1), 1-9. https://doi. org/10.24198/jkk.v4i1.7852

Usman, I. (2013). Kepribadian, komunikasi, kelompok teman sebaya, iklim sekolah dan perilaku bullying. Humanitas (Fakultas Psikologi Universitas Ahmad Dahlan), 10(1), 49-60. https://doi.org/10.26555/ humanitas.v10i1.328.

Watie, E. D. S. (2016). Komunikasi dan media sosial (communications and social media). Jurnal The Messenger, 3(2), 69. https://doi. org/10.26623/themessenger.v3i2.270.

Wijaya, I. S. (2013). Komunikasi interpersonal dan iklim komunikasi. Jurnal Dakwah Tabligh, 14, 115-126.

Griffin, Em. (2012). A First Look at Communication Theory. New York: McGraw-Hill Hatzimoysis, Anthony. (2011). The Philosophy of Sartré. New York: Routledge. Diakses pada 23 Desember 2018 dari: https://remote-lib.ui.ac.id:2195/lib/indonesiau-ebooks/reader.action?docID=1900186\&ppg 